\title{
Small mammal community demography and reproductive seasonality under protection, pastoralism and agriculture in the Serengeti Ecosystem, Tanzania
}

\author{
Monica Shilereyo $^{1,2^{\star}}$, Flora J. Magige ${ }^{2}$, Joseph O. Ogutu ${ }^{3}$ and Eivin Røskaft ${ }^{1}$ \\ ${ }^{1}$ Department of Biology, Norwegian University of Science and Technology (NTNU) Trondheim, Norway. \\ ${ }^{2}$ Department of Zoology and Wildlife Conservation, University of Dar es Salaam, Dar es Salaam, Tanzania. \\ ${ }^{3}$ Biostatistics Unit, Institute for Crop Science, University of Hohenheim, Fruwirthstrasse 23, 70599 Stuttgart, Germany.
}

Received 17 March, 2020; Accepted 18 May, 2020

This work examined population demography and reproductive seasonality among small mammals under protection, pastoralism and agriculture in the Serengeti Ecosystem in 2017 and 2018. Small mammals were trapped to quantify variation in the proportions of actively breeding individuals, juvenile recruitment and adult sex ratio across land use types and seasons. Breeding peaked in the wet season, reflecting a corresponding underlying peak in resource availability and quality. The mean community proportion of reproductively active individuals was greater for females $(60 \%)$ than males $(40 \%)$ and under pastoralism than protection or agriculture. Juvenile recruitment was the highest in the pastoral land in the dry season. Adult sex ratio was biased towards males across all land use types and seasons but towards females in the pastoral than the agricultural land. This concurs with the Trivers-Willard hypothesis that nutritionally stressed females should produce more female offspring. Two generalist and pest species (Mastomys natalensis and Arvicanthis niloticus) dominated the pastoral areas indicating human disturbance. Anthropogenic activities degrade habitats, altering population demographics and promoting habitat generalists and pest species. Protection promotes habitat intactness and reduces opportunistic pests typically abundant in disturbed landscapes. Consequently, enhancing conservation around protected areas can improve diversity and control the abundance of opportunistic pest species.

Key words: Small mammals, seasonal breeding, juvenile recruitment, adult sex ratio, Serengeti ecosystem, pastoralism, agriculture, protection, rainfall, land use.

\section{INTRODUCTION}

Seasonal breeding and population demography are important components of animal population dynamics but can be altered by anthropogenic land use changes that cause habitat degradation and loss (Blaum et al., 2007; Cao et al., 2016). Human activities often replace natural vegetation with managed systems with altered and often

*Corresponding author. E-mail: monicashewona@gmail.com. 
simplified structure, posing threats to biodiversity (Rickart et al., 2013; Schmidt et al., 2005). Such activities therefore threaten biodiversity conservation by reducing the geographic ranges and population sizes of many species (Newbold et al., 2015; Tittensor et al., 2014). Human activities can also adversely affect individual fitness and populations of many species, including small mammals (Bond et al., 2005; Boren et al., 1999; Galbraith, 1988; Hansen et al., 2019; Li et al., 2016; Peles and Barrett, 1996; Schieltz and Rubenstein, 2016; Schmidt et al., 2005). However, the precise consequences of human activities on wildlife vary among species, reflecting their contrasting adaptations to particular habitats and life history strategies, such as the degree of feeding specialization (generalists versus nongeneralists) and timing of breeding.

Small mammals are some of the most important mammals contributing to ecosystem species diversity. Their community structure and species richness are related to variables such as habitat structure, rainfall and productivity (Avenant, 2003). Because land use often alters the availability and quality of essential resources, it can modify the timing and prolificacy of breeding in animals. By shaping food availability, nesting sites and other resources for small mammals, land use can alter their relative competitive abilities and reproductive seasonality (Newsome, 1969a, b). Alterations to natural habitats by land use can modify the constraints imposed by environmental structure and seasonality on the timing, synchrony and fecundity of breeding by small mammals. Even so, rainfall seasonality is a leading meteorological predictor of reproductive seasonality in small mammals in tropical savannas where photoperiod is absent, through its controlling influence on food and surface water availability and quality (Leirs et al., 2010; Lima et al., 2003; Madsen and Shine, 1999; Odhiambo et al., 2005). Rainfall, by modulating food resources, shapes the population abundance and reproductive phenology of small mammals (Bai et al., 2015; Lima et al., 2003; Makundi et al., 2007). As a result, small mammals typically breed seasonally in African savannas with strong rainfall seasonality. For many small mammal species, breeding occurs year-round but with peaks in the transition period between two seasons such that breeding peaks during the early wet season and reduces during the dry season (Francisco et al., 1995; Lima et al., 2003; Wube, 2005).

Seasonal reproduction leads to seasonal recruitment of new-borns and peaks in the number of juveniles at the end of the breeding season (Bantihun and Bekele, 2015). Thus, although juveniles can be found in the population throughout the year, their numbers often peak at the end of the wet season and during the dry season (Gebresilassie et al., 2006; Olenev and Grigorkina, 2011; Oli and Dobson, 1999). Abundant fresh vegetation during the wet season provides small mammals with adequate high-quality food, cover from predators and water for lactating females (Linn, 1991; Massawe et al., 2005).

Reproductive seasonality in mammals is often associated with changes in population demographic characteristics, such as sex ratio. Sex ratio is an important demographic parameter underpinning population fluctuations in mammals (Oli and Dobson, 1999) and is balanced for some populations or population segments but unbalanced for others (Bantihun and Bekele, 2015; Mulungu et al., 2013). At birth, mammals produce approximately equal numbers of males and females resulting in a balanced sex ratio (Rosenfeld and Roberts, 2004), anthropogenic activities can, however, strongly bias sex ratios with significant implications for population dynamics (Marealle et al., 2010; Ndibalema, 2009; Setsaas et al., 2007). Human activities can also indirectly skew sex ratios in mammals by influencing maternal body condition, type and nutritional sufficiency of the diet, competitive ability and stress levels (Hoffmann et al., 2003; Hunninck et al., 2018; Li et al., 2016; Rosenfeld and Roberts, 2004; Trivers and Willard, 1973). Biased sex ratio can have manifold population-level consequences, which can be sex specific and include heightened competition for mates (Fritzsche et al., 2016; Kvarnemo and Ahnesjo, 1996; Schärer et al., 2012), elevated risk of population decline and local extirpation (Le Galliard et al., 2005; Rankin et al., 2011) and breeding depression (Brook et al., 2002; Stephens and Sutherland, 1999).

Although small mammals have been widely studied in many ecosystems, including the Serengeti (Magige and Senzota, 2006; Makundi et al., 2007; Stanley et al., 2011), the variation in their breeding and population demography (abundance, age and sex ratios and juvenile recruitment) across seasons and land use types has attracted relatively little attention. Here, we investigate the influence of seasonality and land use on the breeding activity and population demography of small mammals in the Serengeti Ecosystem. Specifically, we examine seasonal variation in 1) relative abundance of actively breeding females and males, 2) juvenile recruitment among three contrasting land use types and 3) adult sex ratio.

We test predictions of the following seven hypotheses: (H1) The mean breeding probability for males and females should be higher for the wet than the dry season because the wet season receives higher rainfall and thus has higher resource availability and quality for small mammals (Kelly et al., 2013; Sarli et al., 2016; Taylor and Green, 1976). (H2) Further, the mean breeding probability should be higher for males than females in both seasons and in all the three land use types because females spend much more time on reproduction (gestation and rearing young) than males (Johnson et al., 2001). (H3) Because human activities such as cultivation and livestock grazing disturb small mammals, breeding probability should be higher in the protected area than in either the agricultural or the pastoral land. (H4) For the 
same reason, juvenile recruitment is expected to be higher in the protected area than the agricultural or pastoral land. (H5) Juvenile recruitment should also be higher in the dry than the wet season if breeding peaks in the wet season. (H6) Adult sex ratio should be skewed in favour of females in the wet season but in favour of males in the dry season because female small mammals aggressively defend territories in the wet season and the majority of young females are philopatric whereas adult and juvenile males disperse from their natal home ranges to search for mates and food elsewhere (Barrett and Feldhamer, 2008). Furthermore, the local resource competition theory predicts that females should preferentially produce female offspring when resources are plentiful but male offspring when resources are limiting to minimize competition (Clark, 1978; Twining et al., 2017). (H7) Thus, males should be more abundant in the pastoral land due to relatively lower food availability caused by intense livestock grazing but females should be more abundant in the agricultural land and protected area, with potentially higher food availabilities.

\section{MATERIALS AND METHODS}

\section{Study area}

Data on small mammals were collected on the North-eastern part of the Serengeti ecosystem, encompassing the Serengeti National Park $\left(2^{\circ} 20^{\prime} \mathrm{S}, 34^{\circ} 50^{\prime} \mathrm{E}\right)$ and the adjoining Serengeti $\left(2^{\circ} 15^{\prime} \mathrm{S}\right.$, $\left.34^{\circ} 68^{\prime} \mathrm{E}\right)$ and Ngorongoro $\left(3^{\circ} 24^{\prime} \mathrm{S}, 35^{\circ} 48^{\prime} \mathrm{E}\right)$ Districts. Serengeti National Park protects about $15,000 \mathrm{~km}^{2}$ of tropical savanna ecosystem (Sinclair, 2008). The park encompasses a wide variety of vegetation types, including woodlands, treed grasslands, open grasslands and other more restricted habitat types (Byrom et al., 2014; Reed et al., 2009). Farming and livestock pastoralism are practiced in the vicinity of the protected area. Rainfall is bimodal and peaks in the short (November-January) and long (March-May) rainy seasons (Norton-Griffiths et al., 1975). There is a strong gradient of increasing rainfall from the dry south-eastern plains (700 $\mathrm{mm} /$ year) to the wet north-western woodlands (1,050 mm/year) inside the Serengeti National Park. The total monthly rainfall during the study period (2017-2018) averaged $100 \mathrm{~mm}$ for the wet and 62 $\mathrm{mm}$ for the dry season. During the same period, the daily temperature averaged $26^{\circ} \mathrm{C}$ in the wet and $24^{\circ} \mathrm{C}$ in the dry season.

\section{Study design}

The study was carried out along the Mto Wa Mbu-Musoma road transect (Serengeti northern road), which traverses protected, agricultural and pastoral land use types. The transect was selected because it crosses agricultural lands (north-west), pastoral lands with limited agriculture (north-east) and the protected Serengeti National Park situated between these two land use types (Figure 1). Each of the three land use types was subdivided into four plots, for a total of 12 plots ("habitats"). Out of the 12 habitats (plots), 10 were selected for trapping small mammals. The selected 10 habitats were categorized into five habitat types and included four habitat types (riverine forest, shrubland, wooded grassland and grassland) in the Serengeti National Park, four habitat types (shrubland, cropland, grassland and wooded grassland) in the agricultural lands and two habitat types (cropland and shrubland) in the pastoral lands. A noteworthy difference in farming systems between the pastoral and agricultural lands is that the fallow period is relatively longer in the pastoral than the agricultural land. In this study, maize and bean croplands represented cropland habitats.

\section{Trapping procedures}

Traps were set within a $100 \times 100 \mathrm{~m}$ sub-plot in each of the 10 plots (habitats). A total of 141 traps (100 Sherman, 30 wire mesh and 11 bucket pitfall traps) were set in each sub-plot for five consecutive nights and then transferred to the next sub-plot. The wire mesh traps are funnel-shaped, multi-capture traps made of thin wire and are widely used in Tanzania by local hunters. They have one door which allows an animal to enter but not to leave the trap because of inward projecting wires that form an effective barrier to exit.

Each sub-plot was assigned one pitfall line consisting of 11 buckets, spaced $5 \mathrm{~m}$ apart, and buried into the ground such that the top of the bucket was at the ground level. Each of the 11 buckets per plot was buried $26 \mathrm{~cm}$ deep and had a $15 \mathrm{~L}$ capacity, upper and lower diameters of 26 and $24 \mathrm{~cm}$, respectively. Each pitfall line had $50 \mathrm{~cm}$ high black plastic drift fence running over the center of each bucket. These non-baited traps captured animals moving on the habitat floor that encountered the drift fence after following the trail and falling into a bucket. A similar procedure has been used with considerable success in other small mammal surveys (Byrom et al., 2014; Nkwabi et al., 2018; Stanley et al., 2011). For the Sherman traps $(23 \times 9.5 \times 8 \mathrm{~cm}), 10$ lines spaced $10 \mathrm{~m}$ apart were set up in the grid. Sherman traps were arranged along the lines at $10 \mathrm{~m}$ intervals for a total of 100 traps per sub-plot. To maximize capture of a wide variety of species; 30 wire mesh traps ('mgono') were placed in-between and after every Sherman trap line such that in every Sherman line five wire mesh traps were placed $20 \mathrm{~m}$ apart. Freshly fried coconut coated with peanut butter and mixed with Lake Victoria sardine (Rastrineobola argentea) was used as a bait and traps were rebaited twice daily, in the morning (6.30-8.30 am) and late afternoon (17:00-19:00 pm). All traps were checked twice daily, early in the morning (6.30-8.30 am) and early evening (17:0019:00 pm). Both in 2017 and 2018, traps were laid out in April-May in the wet season and in August-September in the dry season. Traps stayed in one plot for five consecutive days. Using Kingdon (2015) and Kirsten et al. (2010) as guides, we identified trapped animals to the genus or species and recorded their morphometric (external shape and dimensions) measurements. Moreover, individually distinctive features, including sex, size, reproductive status and presence of scars were recorded and used to aid individual identification (Graham and Lambin, 2002; Kirsten et al., 2010).

Captured individuals were aged using body size, fur colour and texture. The animals were sub-divided into juvenile and adult age classes. Juveniles and subadults have smaller body size, greyer, softer and down-like baby fur, and typically have not undergone the changes associated with adulthood such as reproductive development (Searle, 1985). By contrast, adults have larger body size, different fur colour patterns and texture and fully developed reproductive organs (Kingdon, 2015; Searle, 1985). All adults and sub-adults were amalgamated together as "adults" whereas all young individuals and juveniles were lumped together as "juveniles" to minimize the likelihood of misclassification. Individuals were sexed using external genitalia and secondary sexual characteristics such as the presence of testes, status of nipples, number of urogenital openings (three in shrews) and distance between the anus and urinogenital opening, which is relatively shorter for female than male rodents (Carraway, 2009; Kunz et al., 1996). To ascertain whether an animal was actively breeding, we noted the breeding status of every individual by examining the position of the testes; scrotal or abdominal in males and perforated or imperforated vagina in females. During the breeding season, males have descended testes caused by a temporary bulge in the perineal 


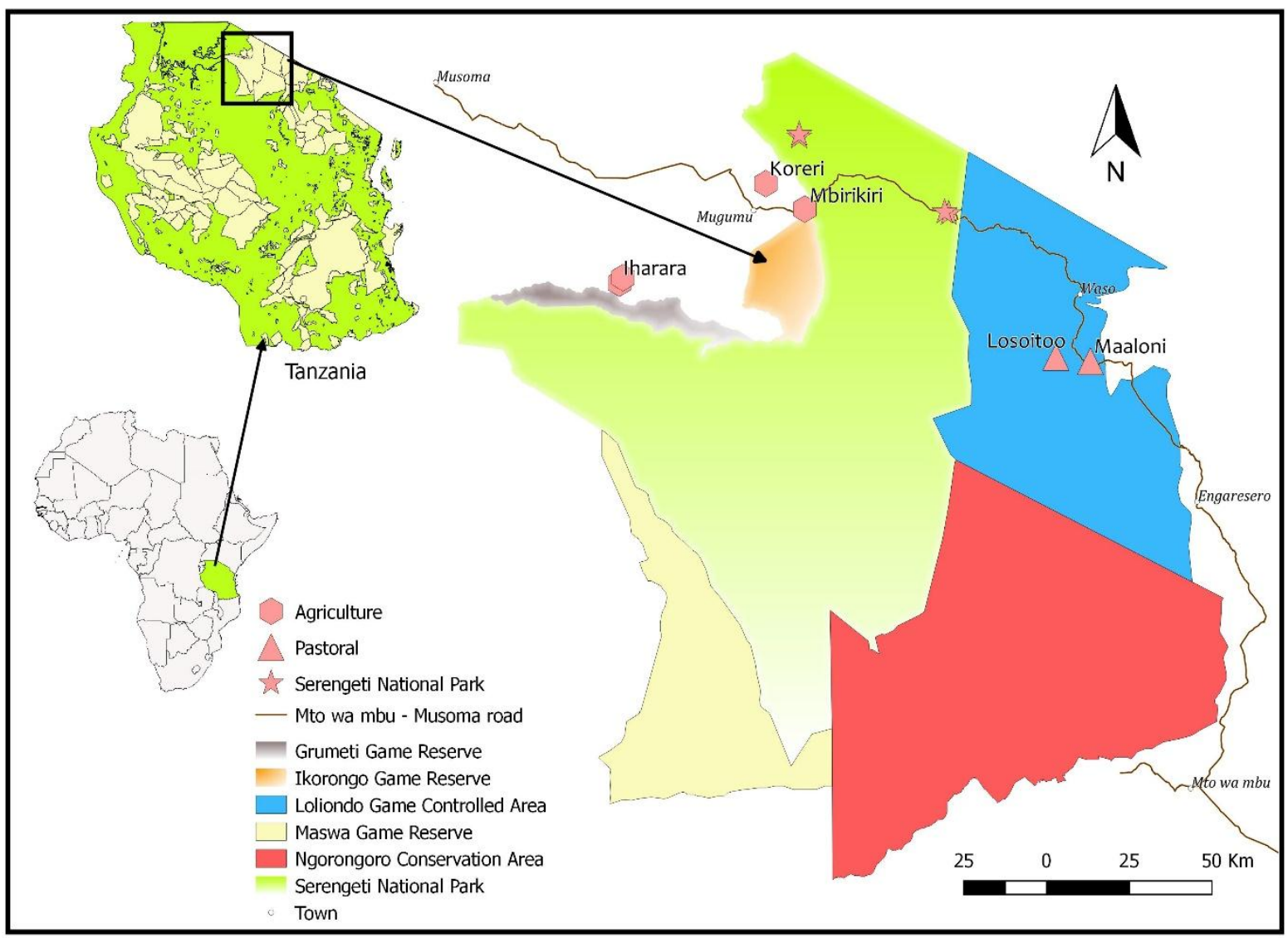

Figure 1. Map of the Serengeti Ecosystem showing the study area including the Mto Wa Mbu - Musoma road transect (study plots are in pink colour).

region (between the anus and the urinogenital opening) whereas females have a swollen vaginal tissue and gaping vaginal opening. Animals whose sex and breeding status could not be accurately determined were classed as "undefined" and excluded from the statistical analyses involving either trait. In particular, juveniles were hard to sex accurately and hence were omitted from all analyses involving sex ratios. As a result, only "adults" (adults and subadults), which were accurately identified to sex ( $n=552$ of 566 adults), were included in analyses involving information on the sex of captured individuals. Similar methods have been used previously to sex, age and ascertain the breeding status of small mammals (Makundi et al., 2007; Monadjem and Perrin, 2003).

\section{Statistical analyses}

We used a generalized linear model with a binomial error distribution and logit link function (logistic regression) to analyse the variation in the community proportion of all actively breeding small mammals (number of breeding adults of all species/number of all adults of all species) with season, land use, sex and all their interactions. We used the logarithm of the total trap nights per land use type as an offset to account for variation in total trap nights across the three land use types. We calculated adjusted mean breeding probabilities for all significant main effects and interactions. We also performed a partitioned analysis of the adjusted mean breeding probabilities for the significant interaction effects (analysis of simple effects) (Winer, 1971), carried out pairwise comparisons of the adjusted mean probabilities and adjusted the family wise error rate for multiplicity by using simulation adjustment (S1 Data). We similarly analysed variation in juvenile recruitment (juveniles/(juveniles + adults, S2 Data) across seasons, land use and their interaction and variation in adult male: female ratio (Males+Females) across land use types and seasons (Becker et al., 2016). The logistic regression models were implemented in the SAS GLIMMIX procedure (SAS Institute 2019, SAS/STAT Version 15.1).

\section{RESULTS}

A total of 612 small mammals consisting of 18 rodent species $(n=528,86 \%)$ and one genus of shrews $(n=84$, $14 \%$ ) were trapped and recorded during 28,200 trap nights of effort. Adults constituted $92.5 \%$ whereas juveniles $7.5 \%$ of all the 612 captured small mammals. Of the 566 adults, $65.7 \%$ were males, $31.8 \%$ were females; whereas $2.5 \%$ were not identified to sex. Four species dominated the captured small mammals, namely Arvicanthis niloticus $(n=162)$, Mastomys natalensis $(n=$ 101), Mus sp $(n=91)$ and Crocidura sp $(n=84)$. The two most abundant species ( $A$. niloticus and $M$. natalensis) were particularly abundant on the pastoral landscape 


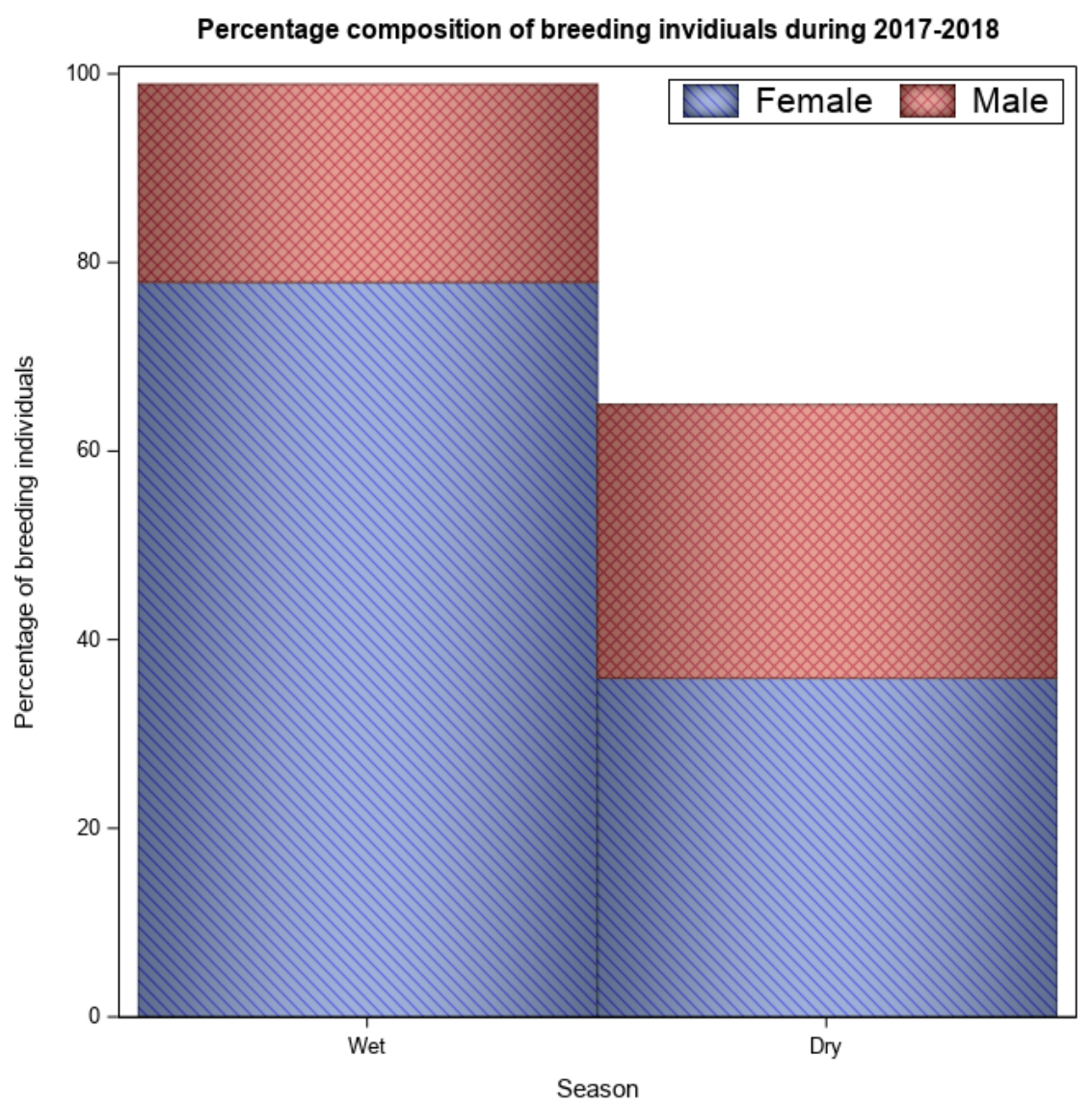

Figure 2. Percentage composition of the actively breeding female and male small mammals captured in the Serengeti ecosystem during the wet and dry seasons of 2017 and 2018.

where they contributed $73 \%$ of all the 96 actively breeding individuals captured.

\section{Variation in breeding activity across sexes, seasons and land use types}

Out of the 566 adults trapped, $167(47 \%)$ were actively breeding and consisted of $67(40 \%)$ males and 100 $(59.8 \%)$ females. The mean breeding probability was higher for the wet than the dry season (Figure 2) because substantially more males and females were engaged in breeding activity in the wet than the dry season (Tables 1-3) as predicted ( $\mathrm{H} 1)$. As well, more females than males were engaged in breeding activity in both the wet and dry seasons (Tables 1 to 3 and Table S1), contrary to the prediction $(\mathrm{H} 2)$ that the mean breeding probability should be higher for males than females regardless of land use or season.

In addition, the mean breeding probability differed across land use types but was surprisingly the highest for the pastoral, intermediate for the agricultural and lowest for the protected land (Figure 3 and Tables 1 and 2), contrary to the prediction that it should be the highest for the protected area $(\mathrm{H} 3)$. The mean breeding probability for each land use type was, moreover, similar for both males and females and for the wet and dry seasons (Table 1).

\section{Variation in juvenile recruitment across seasons and land use types}

The mean juvenile recruitment was higher for the dry $(10.5 \%)$ than the wet season $(3.2 \%, n=612$; Tables 4 and 5, Table $\mathrm{S} 2$ ) as predicted ( $\mathrm{H} 5)$. The mean juvenile recruitment was also higher for the pastoral land than for either the protected or the agricultural land, both of which had comparable mean recruitment probabilities (Tables 4 and 5, Table S2); a pattern inconsistent with the prediction that it should be the highest for the protected area $(\mathrm{H} 4)$.

\section{Variation in adult sex ratio across seasons and land use types}

Sex ratio was biased in favour of males for both the wet 
Table 1. Tests of fixed effects of land use, season, sex and their interactions on variation in breeding probability of small mammals trapped in the Serengeti ecosystem during 2017 and 2018 based on the logistic regression model.

\begin{tabular}{lcccc}
\hline Effect & NDF & DDF & F & Pr $>$ F \\
\hline Landuse & 2 & 11 & 20.46 & 0.0002 \\
Season & 1 & 11 & 23.63 & 0.0005 \\
Landuse Season & 2 & 11 & 0.94 & 0.4203 \\
Sex & 1 & 11 & 33.16 & 0.0001 \\
Landuse $\times$ Sex & 2 & 11 & 1.06 & 0.3794 \\
Season $\times$ Sex & 1 & 11 & 7.22 & 0.0211 \\
Landuse $\times$ Season $\times$ Sex & 2 & 11 & 0.06 & 0.9466 \\
\hline
\end{tabular}

NDF and DDF are the numerator and denominator degrees of freedom, respectively.

Table 2. Adjusted mean breeding probability and the associated $95 \%$ confidence limits (CL) for small mammals trapped in the Serengeti Ecosystem during 2017 and 2018 based on the logistic regression model.

\begin{tabular}{|c|c|c|c|c|c|c|c|}
\hline Effect & Landuse & Season & Sex & $\begin{array}{c}\text { Mean } \\
\text { probability }\end{array}$ & $\begin{array}{c}\text { Standard } \\
\text { error }\end{array}$ & $\begin{array}{c}\text { Lower } 95 \% \\
\text { CL } \\
\end{array}$ & $\begin{array}{c}\text { Upper } 95 \% \\
\text { CL }\end{array}$ \\
\hline Landuse & Agricultural & & & 0.3441 & 0.08543 & 0.1857 & 0.5469 \\
\hline Landuse & National park & & & 0.2493 & 0.04076 & 0.1705 & 0.3491 \\
\hline Landuse & Pastoral & & & 0.5375 & 0.05482 & 0.417 & 0.6538 \\
\hline \multicolumn{2}{|c|}{ Season $\times$ Sex } & Dry & $\mathrm{F}$ & 0.3049 & 0.0608 & 0.1891 & 0.4519 \\
\hline \multicolumn{2}{|c|}{ Season $\times$ Sex } & Dry & M & 0.1387 & 0.02709 & 0.0891 & 0.2097 \\
\hline \multicolumn{2}{|c|}{ Season $\times$ Sex } & Wet & $\mathrm{F}$ & 0.8372 & 0.06796 & 0.6318 & 0.9391 \\
\hline \multicolumn{2}{|c|}{ Season $\times$ Sex } & Wet & M & 0.2465 & 0.03859 & 0.1716 & 0.3408 \\
\hline
\end{tabular}

$\mathrm{F}$ and $\mathrm{M}$ denote females and males, respectively.

Table 3. Tests of simple effect slices (decomposition or partitioned analysis) of the interaction between season and sex on variation in breeding probability of small mammals trapped in the Serengeti ecosystem during 2017 and 2018 based on the logistic regression model.

\begin{tabular}{llcccc}
\hline Effect & Slice & NDF & DDF & F & Pr $>$ F \\
\hline Season $\times$ Sex & Sex F & 1 & 11 & 18.31 & 0.0013 \\
Season $\times$ Sex & Sex M & 1 & 11 & 5.31 & 0.0417 \\
Season $\times$ Sex & Season Dry & 1 & 11 & 7.51 & 0.0192 \\
Season $\times$ Sex & Season Wet & 1 & 11 & 26.01 & 0.0003 \\
\hline
\end{tabular}

NDF and DDF are the numerator and denominator degrees of freedom, respectively.

and dry seasons, the protected area and agricultural land but was approximately balanced for the pastoral land (Figure 4, Table 6 and Table S3 and S4). These patterns contradict the prediction that females should be more abundant than males in the wet season but less abundant than males in the dry season $(\mathrm{H} 6)$ as well as the prediction that males should be more abundant than females in the pastoral land $(\mathrm{H} 7)$. Furthermore, pairwise comparisons showed that male sex ratio was higher for the agricultural than the pastoral land but comparable between the agricultural and the protected land. But female sex ratio was higher for the pastoral than the agricultural land but comparable between the pastoral versus the protected land and the agricultural versus the protected land (Table S4).

\section{DISCUSSION}

We examined variation in breeding activity and community demography of small mammals with season and land use in the Serengeti Ecosystem during 2017 and 2018. This involved quantifying seasonal variation in the relative abundance of actively breeding females and males, adult sex ratio and juvenile recruitment among 


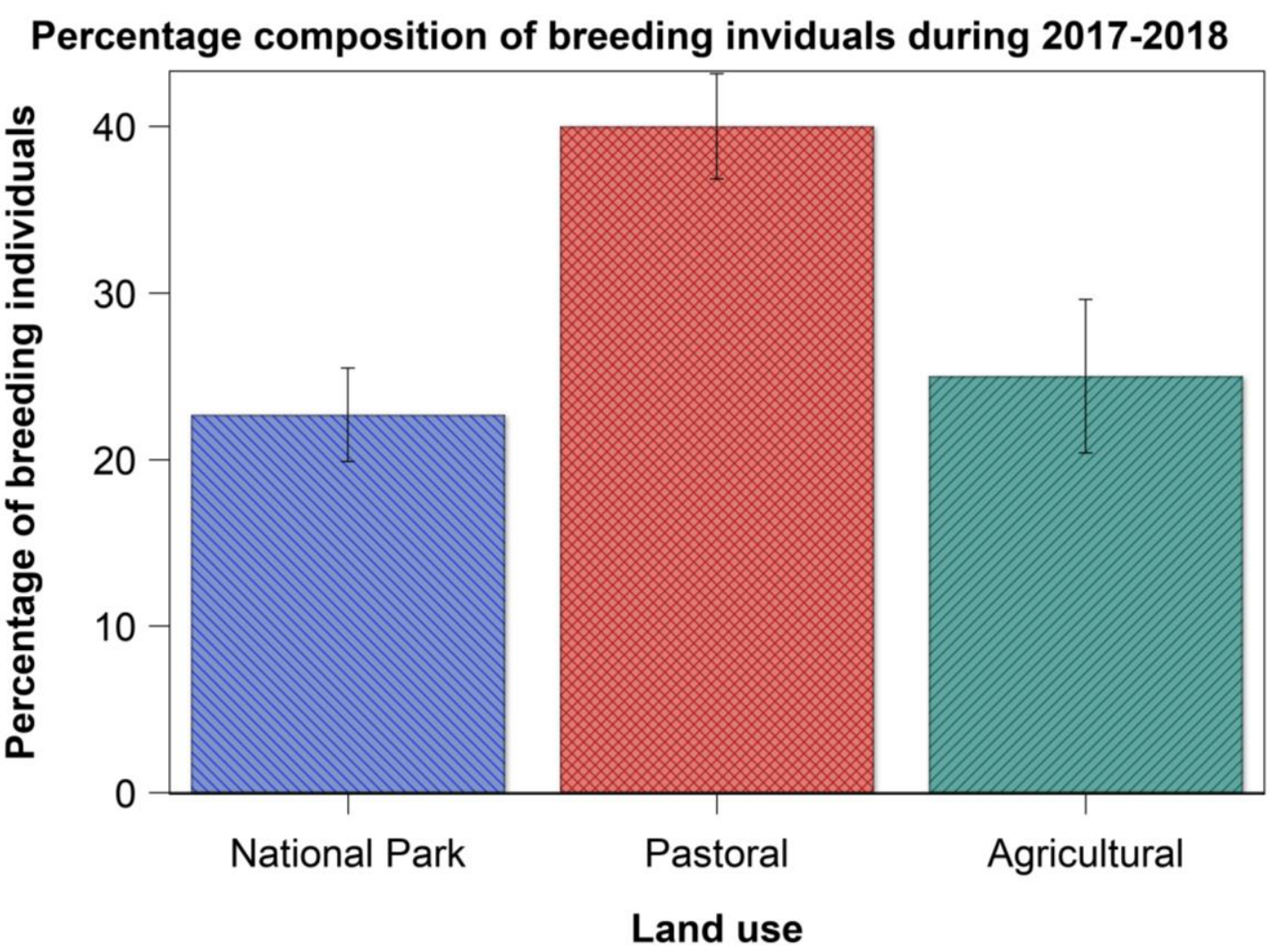

Figure 3. Percentage and the associated standard deviation of the actively breeding individuals captured on three land use types in the Serengeti Ecosystem during 2017 and 2018.

Table 4. Tests of fixed effects of land use and season (the interaction effect between the two factors was dropped because it was insignificant), on variation in juvenile recruitment of small mammals trapped in the Serengeti ecosystem during 2017 and 2018 based on the logistic regression model. NDF and DDF are the numerator and denominator degrees of freedom, respectively.

\begin{tabular}{lcccc}
\hline Effect & NDF & DDF & F Value & Pr $>$ F \\
\hline Landuse & 2 & 8 & 13.72 & 0.0026 \\
Season & 1 & 8 & 6.05 & 0.0393 \\
\hline
\end{tabular}

Table 5. Adjusted mean recruitment probabilities, standard errors and $95 \%$ confidence limits (CL) for small mammals trapped in the Serengeti ecosystem during 2017 and 2018 based on the logistic regression model.

\begin{tabular}{|c|c|c|c|c|c|c|}
\hline Effect & Landuse & Season & Mean probability & Standard error & 95\% Lower CL & 95\% Upper CL \\
\hline Landuse & Agricultural & & 0.049481 & $2.037 \times 10^{-6}$ & 0.018462 & 0.125943 \\
\hline Landuse & National par & & 0.023883 & $9.123 \times 10^{-7}$ & 0.009191 & 0.060625 \\
\hline Landuse & Pastoral & & 0.095993 & $4.344 \times 10^{-6}$ & 0.058714 & 0.153104 \\
\hline Season & & Dry & 0.117526 & $2.138 \times 10^{-6}$ & 0.076605 & 0.183297 \\
\hline Season & & Wet & 0.046776 & $1.309 \times 10^{-6}$ & 0.02044 & 0.104624 \\
\hline
\end{tabular}

three contrasting land use types.

For this small mammal community, breeding activity was higher during the wet than the dry season. This reflects the underlying peak in vegetation cover, drinking water and food availability and quality in the wet season, associated with higher rainfall. 


\section{Small mammal sex ratio in Serengeti Ecosystem during 2017-2018}

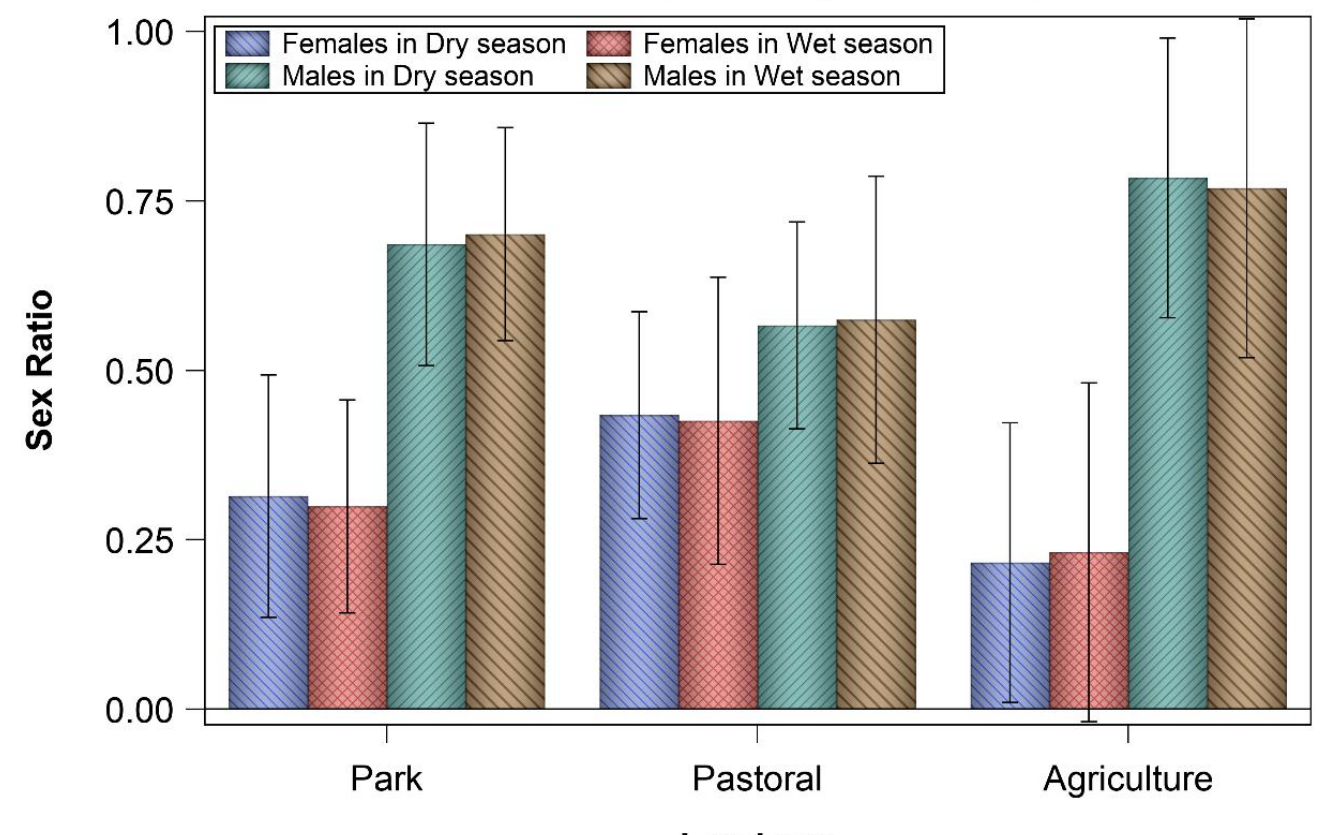

Land use

Figure 4. Small mammal sex ratio and the associated standard deviation across land use types and seasons in the Serengeti Ecosystem during 2017 and 2018.

Table 6. Tests of fixed effects of land use, season, sex and their interactions on variation in sex ratio of small mammals trapped in the Serengeti ecosystem during 2017 and 2018 based on the logistic regression model.

\begin{tabular}{lcccc}
\hline Effect & NDF & DDF & F Value & Pr $>$ F \\
\hline Landuse & 2 & 2 & 0 & 1.0000 \\
Season & 1 & 2 & 0 & 1.0000 \\
Landuse×Season & 2 & 2 & 0 & 1.0000 \\
Sex & 1 & 2 & 133.44 & 0.0074 \\
Landuse $\times$ Sex & 2 & 2 & 21.7 & 0.0441 \\
Season×Sex & 1 & 2 & 0.18 & 0.7144 \\
\hline
\end{tabular}

NDF and DDF are the numerator and denominator degrees of freedom, respectively.

The wet season breeding peak is consistent with expectation and findings of several earlier studies, suggesting that breeding in African small mammals peaks in the wet season with abundant and nutritionally sufficient forage for lactation and rearing young (Bantihun and Bekele, 2015; Makundi et al., 2007; Massawe et al., 2008, 2012; Nicolas and Colyn, 2003). Through its influence on the availability and nutritional sufficiency of forage, rainfall seasonality influences life history strategies and individual fitness of small mammals (Makundi et al., 2007). Rainfall seasonality governs reproductive success in small mammals by indirectly affecting their food supply, such as insects (Linzey and Kesner, 1997), or directly controlling the production of fresh, succulent vegetation and availability of adequate water for lactation (Reichman and Van De Graaff, 1975; Soholt, 1977). Therefore, the small mammal species apparently time their reproduction so that the offspring are weaned at the time of peak resource abundance and quality.

There were more active breeding females than males across all seasons and land use types, thus contradicting the prediction that there should be more breeding males than females. The preponderance of females implies that potentially more juveniles would be recruited into the community if many females survive to successfully mate and reproduce. The number of actively breeding females has been reported to peak at the onset of the breeding season when females search for potential mates but drop from the middle to the end of the breeding season as the 
majority of the females are either pregnant or taking care of young ones (Geary, 2015). Therefore, the larger number of breeding females relative to males in the breeding season suggests that the time of capture likely coincided with the beginning of the breeding season for most of the small mammal species. Alternatively, the short gestation period and postpartum oestrus of some of the small mammal species may have resulted in the presence of many actively breeding females in the population across seasons and land use types.

The skew in operational sex ratio (the sex ratio of ready-to-mate or sexually active individuals) towards females among the sexually active individuals suggests that females were probably competing for male mates whereas the males increased their mating input. This follows from the expectation that competition for mates is likely to occur when operational sex ratio is skewed in favour of one sex (Geary, 2015; Zhang and Zhang, 2003). Specifically, when operational sex ratio is male skewed, then males may compete for mates, but when it is female skewed, then males tend to increase their seasonal mating input (Zhang and Zhang, 2003). However, since we focus on breeding at the community level, further data would be required to establish whether operational sex ratio is similarly biased in favour of females for breeding populations of the individual species.

In the breeding (wet) season, the mean breeding probability of the small mammal community varied across land use types and was higher for the pastoral than the protected land. This contradicts the expectation that this probability should be the highest for the protected land. The relatively large proportion of breeding individuals in the pastoral land is due to the preponderance of $A$. niloticus and $M$. natalensis there. These two species are common in human-disturbed habitats and often numerically dominate other sympatric species (Avenant, 2003; Byrom et al., 2015; Crespin et al., 2008; Magige, 2016). Their numerical dominance in the pastoral land likely reflects disturbance by livestock grazing that creates conditions they favour. Furthermore, since $A$. niloticus and $M$. natalensis species are serious pests in most parts of Africa, their numerical dominance in the shrubland and cropland habitats in the pastoral land implies that habitat conversion by human activities tends to favour pest species. As a result, habitat conversion increases the likelihood of destruction of crops and other properties. It is noteworthy that, although humandisturbed habitats favour breeding of generalist species, protection supports many species that avoid disturbed areas in the breeding season.

Juvenile recruitment into the community was higher during the dry than the wet season as a result of the higher breeding activity during the wet season. This implies that the small mammals match their breeding activities with rainfall patterns, resulting in more juveniles in the dry season. This supports the prediction that juvenile recruitment in the ecosystem should be significantly higher in the dry than the wet season. Similar patterns have been reported by other studies (Gentile et al., 2000; Mulungu et al., 2013; Williams et al., 2017; Wirminghaus and Perrin, 1993) and imply that seasonality in juvenile recruitment is driven by resource seasonality such that juveniles join the community in the late wet and early dry seasons when high-quality resources critical for their survival and contributed by the previous rainfall season are abundant. This corroborates observations of other mammals and birds that recruitment is typically timed to match seasonal peaks in resource availability and quality to maximize fitness (Visser and Both, 2005) and enhance population growth (Habtamu and Bekele, 2008; Lima et al., 2003). Although the majority of the juveniles was recorded in the community in the dry season, few were also found in the wet season, reflecting inter-specific distinctions in the length and timing of breeding and growth rates (Oli and Dobson, 1999). Therefore, monthly monitoring would be necessary to accurately determine responses to resource seasonality of juvenile recruitment, operational sex ratio and breeding activity patterns in populations of individual small mammal species.

Higher juvenile recruitment for the pastoral land than for both the agricultural and the protected lands contradicts the prediction that it should be higher for the protected land. This is largely due to the presence of the larger number of actively breeding individuals in the pastoral land in the wet season. Notably, the twogeneralist species ( $A$. niloticus and $M$. natalensis) contributed $>50 \%$ of actively breeding individuals in the pastoral land. Thus, the higher juvenile recruitment among the generalist species in the pastoral land reflects the influence of human activities, supporting the observation that these two species thrive better in human-disturbed habitats (Assefa and Chelmala, 2019; Getachew et al., 2016; Magige, 2016). Livestock grazing and agriculture, the two predominant forms of human activities in the pastoral land, typically alter plant structure and create simplified habitats that favour generalist species (Jones and Longland, 1999; Keesing, 1998; Luza et al., 2016; Tabeni and Ojeda, 2005). Consequently, intense grazing in the pastoral land apparently simplify habitats, thereby favouring breeding by generalist species and leading to a higher mean juvenile recruitment relative to the other two land use types. Low recruitment in the agricultural land could be due primarily to the cropping systems used. It typically takes less than a month to prepare land by oxen and replant because most of the farmers cultivate crops for cash income (Makundi et al., 1999; Massawe et al., 2003). Thus, the cropping system used in the agricultural land likely contributed to a relatively less stable supply and availability of food and shelter for the small mammal species after harvests (Massawe et al., 2006, 2003). Alternatively, the lower juvenile recruitment in the 
protected and agricultural than in the pastoral land can be interpreted as indicating that many species probably breed in both land use types at other times of the year not covered by this study.

Sex ratio was male biased, both in the wet and dry seasons. This contradicts the prediction that females should be more abundant than males in the wet season but less abundant than males in the dry season. The male-biased sex ratio is probably due to the tendency of males travelling long distances than females, resulting in a higher probability of getting trapped (Bantihun and Bekele, 2015; Clapperton, 2006; D'Andrea et al., 1999; Duque et al., 2005; Phelps, 2006). Although sex ratio was male skewed for both seasons, it might be due to differences in the amount of reproductive effort invested between sexes such that females spend more time caring for the young than males (Breedveld et al., 2019; Johnson et al., 2001). In addition, females become more risk-averse during pregnancy or lactation, and hence more wary when encountering unfamiliar situations which would make them less trappable than males (Dickman, 1999). Furthermore, the skew in sex ratio towards males in the agricultural and protected lands than in the pastoral land contradicts the prediction that males should be more abundant in the pastoral land whereas females should favour the agricultural and protected lands. However, the higher sex ratio in favour of females in the pastoral than the agricultural or protected land agrees with the prediction that females in good body condition tend to give birth to more males than nutritionally stressed females (Trivers and Willard, 1973). It follows that females in the pastoral land (with likely food shortages) might be giving birth to more females whereas females in the protected and agricultural lands (with likely greater food availability) to more males. This is expected because livestock grazing reduces food quality and quantity compared to protection, while agricultural land provides abundant but more seasonal food supply to small mammals especially when crops ripen and just after harvests (Caro, 2001; Jones and Longland, 1999; Keesing, 1998; Tabeni and Ojeda, 2005). Consequently, females probably have better body condition due to their access to relatively higher food availability in the protected and agricultural lands than in the pastoral land. When population sex ratio is male skewed it may affect the entire population by further reducing the number of available females through stress and competition for mates (Rankin et al., 2011). Also, it can be more problematic because higher male-male competition and the production of fewer offspring are all detrimental to population growth and viability (Grayson et al., 2014; López-Sepulcre et al., 2009).

\section{Conclusion}

The Serengeti small mammal community showed strong breeding seasonality with active breeding peaking in the wet season. Availability and quality of resources resulted in a peak in juvenile recruitment in the early dry season. Small mammal breeding and recruitment varied across land use types in both the wet and dry seasons, reflecting spatial distinctions in resource availability and quality related to contrasting land uses. Specifically, mean breeding and recruitment probabilities for $M$. natalensis and $A$. niloticus species were higher in the pastoral land than the protected and agricultural lands, suggesting that livestock grazing simplified small mammal habitats in the pastoral land, favouring generalist species. Adult sex ratio varied seasonally and across land use types and was male skewed, with potentially adverse consequences for juvenile recruitment, population growth and viability. However, skewed sex ratio towards females for the pastoral than the agricultural or protected land reinforces the prediction of the Trivers-Willard hypothesis that females in poor body condition should give birth to more females than the presumably nutritionally less stressed females in the protected or agricultural land. Accordingly, human alterations to natural habitats degrade and simplify habitats, favouring generalist species, including some serious pest species, and altering small mammal breeding patterns and population demography. It follows that protection, by enhancing habitat intactness helps enhance species richness by reducing opportunistic pest species that typically numerically dominate disturbed habitats.

\section{CONFLICT OF INTERESTS}

The authors have not declared any conflict of interests.

\section{REFERENCES}

Assefa A, Chelmala S (2019). Comparison of rodent community between natural and modified habitats in Kafta-Sheraro National Park and its adjoining villages, Ethiopia: implication for conservation. The Journal of Basic and Applied Zoology 80(1):59.

Avenant NL (2003). The use of small mammal community characteristics as an indicator of ecological disturbance in the Korannaberg Conservancy. ACIAR Monograph Series 96:95-98.

Bai Y, Xu Z, Lu B, Sun Q, Tang W, Liu X, Yang W, Xu X, Liu Q (2015). Effects of climate and rodent factors on hemorrhagic fever with renal syndrome in Chongqing, China. PLoS ONE 10(7):1997-2008.

Bantihun G, Bekele A (2015). Population structure of small mammals with different seasons and habitats in Arditsy Forest, Awi Zone, Ethiopia. International Journal of Biodiversity and Conservation 7(8):378-387.

Barrett GW, Feldhamer GA (2008). The golden mouse: ecology and conservation. Springer.

Becker JB, Prendergast BJ, Liang JW (2016). Female rats are not more variable than male rats: a meta-analysis of neuroscience studies. Biology of Sex Differences 7(1):34.

Blaum N, Rossmanith E, Jeltsch F (2007). Land use affects rodent communities in Kalahari savannah rangelands. African Journal of Ecology 45(2):189-195.

Bond G, Burnside NG, Metcalfe DJ, Scott DM, Blamire J (2005). The effects of land-use and landscape structure on barn owl (Tyto alba) breeding success in southern England, UK. Landscape Ecology 
20(5):555-566

Boren JC, Engle DM, Palmer MW, Masters RE, Criner T (1999). Land use change effects on breeding bird community composition. Rangeland Ecology and Management/Journal of Range Management Archives 52(5): 420-430.

Breedveld MC, Folkertsma R, Eccard JA (2019). Rodent mothers increase vigilance behaviour when facing infanticide risk. Scientific Reports 9(1):1-10.

Brook BW, Tonkyn DW, O'Grady JJ, Frankham R (2002). Contribution of inbreeding to extinction risk in threatened species. Conservation Ecology 6(1).

Byrom AE, Craft ME, Durant SM, Nkwabi AJ, Metzger K, Hampson K, Mduma SA, Forrester GJ, Ruscoe WA, Reed DN (2014). Episodic outbreaks of small mammals influence predator community dynamics in an east African savanna ecosystem. Oikos 123(8):1014-1024.

Byrom AE, Nkwabi AJ, Metzger K, Mduma SA, Forrester GJ, Ruscoe WA, Reed DN, Bukombe J, Mchetto J, Sinclair A (2015). Anthropogenic stressors influence small mammal communities in tropical East African savanna at multiple spatial scales. Wildlife Research 42(2):119-131.

Cao C, Shuai L-Y, Xin X-P, Liu Z-T, Song Y-L, Zeng Z-G (2016). Effects of cattle grazing on small mammal communities in the Hulunber meadow steppe. Peer Journal 4:e2349.

Caro T (2001). Species richness and abundance of small mammals inside and outside an African national park. Biological Conservation 98(3):251-257.

Carraway LN (2009). Determining sex of Sorex shrews (Soricomorpha: soricidae). The American Midland Naturalist 162(1):87-97.

Clapperton BK (2006). A review of the current knowledge of rodent behaviour in relation to control devices (Vol. 263): Science \& Technical Pub., Department of Conservation. https://www.doc.govt.nz/documents/science-andtechnical/SFC263.pdf. Last visited on 9th May 2020

Clark AB (1978). Sex ratio and local resource competition in a prosimian primate. Science 201(4351):163-165.

Crespin L, Papillon Y, Abdoulaye D, Granjon L, Sicard B (2008). Annual flooding, survival and recruitment in a rodent population from the Niger River plain in Mali. Journal of Tropical Ecology 24(4):375-386.

D'Andrea PS, Gentile R, Cerqueira R, Grelle CEV, Horta C, Rey L (1999). Ecology of small mammals in a Brazilian rural area. Revista Brasileira de Zoologia 16(3): 611-620.

Dickman CR (1999). Rodent-ecosystem relationships: a review. Ecologically-based management of rodent pests. ACIAR Monograph (59):113-133.

Duque U, Joshi R, Martin A, Marquez L, Sebastian L (2005). Rat pest species breeding patterns in the trap barrier system plus a trap crop (TBS+ TC) at the PhilRice-CES farm: management implications. International Rice Research Notes 30(1):26.

Francisco ADL, Magnusson WE, Sanaiotti TM (1995). Variation in growth and reproduction of Bolomys lasiurus (Rodentia: Muridae) in an Amazonian savanna. Journal of Tropical Ecology 11(3):419-428.

Fritzsche K, Booksmythe I, Arnqvist G (2016). Sex ratio bias leads to the evolution of sex role reversal in honey locust beetles. Current Biology 26(18):2522-2526.

Galbraith H (1988). Effects of agriculture on the breeding ecology of lapwings Vanellus vanellus. Journal of Applied Ecology (25):487-503.

Geary DC (2015). Evolution of vulnerability: Implications for sex differences in health and development: Academic Press. https://psycnet.apa.org/record/2016-08013-000. Last accessed January $10^{\text {th }}, 2019$.

Gebresilassie W, Bekele A, Belay G, Balakrishnan M (2006). Home range and reproduction of rodents in Maynugus irrigation field, northern Ethiopia. SINET: Ethiopian Journal of Science 29(1):57-62.

Gentile R, D'Andrea PS, Cerqueira R, Santoro Maroja L (2000). Population dynamics and reproduction of marsupials and rodents in a Brazilian rural area: a five-year study. Studies on Neotropical Fauna and Environment 35(1):1-9.

Getachew G, Balakrishnan M, Bekele A (2016). Species composition and habitat association of rodents in Yetere Forest, Central Ethiopia. International Journal of Ecology and Environmental Sciences 42(3):193-200.

Graham IM, Lambin X (2002). The impact of weasel predation on cyclic field-vole survival: the specialist predator hypothesis contradicted. Journal of Animal Ecology 71(6):946-956.

Grayson KL, Mitchell NJ, Monks JM, Keall SN, Wilson JN, Nelson NJ (2014). Sex ratio bias and extinction risk in an isolated population of tuatara (Sphenodon punctatus). PLoS ONE 9(4):e94214.

Habtamu T, Bekele A (2008). Habitat association of insectivores and rodents of Alatish National Park, northwestern Ethiopia. Tropical Ecology 49(1):1.

Hansen BD, Fraser HS, Jones CS (2019). Livestock grazing effects on riparian bird breeding behaviour in agricultural landscapes. Agriculture, Ecosystems and Environment 270:93-102.

Hoffmann IE, Millesi E, Huber S, Everts LG, Dittami JP (2003). Population dynamics of European ground squirrels (Spermophilus citellus) in a suburban area. Journal of Mammalogy 84(2):615-626.

Hunninck L, Ringstad IH, Jackson CR, May R, Fossøy F, Uiseb K, Killian W, Palme R, Røskaft E (2018). Being stressed outside the park-conservation of African elephants (Loxodonta africana) in Namibia. Conservation Physiology 6(1):cox080.

Johnson M, Thomson S, Speakman JR (2001). Limits to sustained energy intake: II. Inter-relationships between resting metabolic rate, life-history traits and morphology in MUS MUSCULUS. Journal of Experimental Biology 204(11):1937-1946.

Jones AL, Longland WS (1999). Effects of cattle grazing on salt desert rodent communities. The American Midland Naturalist 141(1):1-12.

Keesing F (1998). Impacts of ungulates on the demography and diversity of small mammals in central Kenya. Oecologia 116(3):381389

Kelly LT, Dayman R, Nimmo DG, Clarke MF, Bennett AF (2013). Spatial and temporal drivers of small mammal distributions in a semi-arid environment: The role of rainfall, vegetation and life-history. Austral Ecology 38(7):786-797.

Kingdon $J$ (2015). The Kingdon field guide to African mammals: Bloomsbury Publishing. p. 640.

Kirsten F, Richardson EJ, Peplow C (2010). ECORAT; Key to small mammals commonly found in agricultural areas in Eastern and Southern Africa. Last accessed on 10/2/2020 at1400hrs.

Kunz TH, Wemmer C, Hayssen V (1996). Sex, age, and reproductive condition of mammals. Measuring and monitoring biological diversity: standard methods for mammals (Wilson DE, Cole FR, Nichols JD, Rudran R, Foster MS, eds.). Smithsonian Institution Press, Washington, DC pp.279-290.

Kvarnemo C, Ahnesjo I (1996). The dynamics of operational sex ratios and competition for mates. Trends in Ecology and Evolution 11(10):404-408.

Le Galliard J-F, Fitze PS, Ferrière R, Clobert J (2005). Sex ratio bias, male aggression, and population collapse in lizards. Proceedings of the National Academy of Sciences 102(50):18231-18236.

Leirs H, Sluydts V, Makundi R (2010). Rodent outbreaks in subSaharan Africa. Rodent Outbreaks: Ecology and Impacts pp. 290.

Li G, Hou X, Wan X, Zhang Z (2016). Sheep grazing causes shift in sex ratio and cohort structure of Brandt's vole: Implication of their adaptation to food shortage. Integrative Zoology 11(1):76-84.

Lima M, Stenseth NC, Leirs H, Jaksic FM (2003). Population dynamics of small mammals in semi-arid regions: a comparative study of demographic variability in two rodent species. Proceedings of the Royal Society of London B: Biological Sciences 270(1528):19972007.

Linn I (1991). Influence of 6-methoxybenzoxazolinone and green vegetation on reproduction of the multimammate rat Mastomys coucha. South African Journal of Wildlife Research-24-month delayed open access 21(2):33-37.

Linzey A, Kesner M (1997). Small mammals of a woodland-savannah ecosystem in Zimbabwe. I. Density and habitat occupancy patterns. Journal of Zoology 243(1):137-152.

López-Sepulcre A, Norris K, Kokko H (2009). Reproductive conflict delays the recovery of an endangered social species. Journal of Animal Ecology 78:219-225.

Luza AL, Gonçalves GL, Pillar VD, Hartz SM (2016). Processes related to habitat selection, diversity and niche similarity in assemblages of non-volant small mammals at grassland-forest ecotones. Natureza and Conservacao 14(2):88-98.

Madsen T, Shine R (1999). Rainfall and rats: Climatically-driven 
dynamics of a tropical rodent population. Australian Journal of Ecology 24(1):80-89.

Magige $F$ (2016). Variation of small mammal populations across different habitat types in the Serengeti ecosystem. Tanzania Journal of Science 42(1):15-23.

Magige F, Senzota R (2006). Abundance and diversity of rodents at the human-wildlife interface in western Serengeti, Tanzania. African Journal of Ecology 44(3): 371-378.

Makundi RH, Massawe AW, Mulungu LS (2007). Breeding seasonality and population dynamics of three rodent species in the Magamba Forest Reserve, Western Usambara Mountains, north-east Tanzania. African Journal of Ecology 45(1):17-21.

Makundi RH, Oguge NO, Mwanjabe PS (1999). Rodent pest management in East Africa-an ecological approach. In: Ecologically based Rodent Management (Eds Singleton G, Hinds L, Leirs H, Zhang Z). Australian Center For International Agricultural Research, Canberra, Australia. In: Rodent Pest Management in East Africa.

Marealle WN, Fossøy F, Holmern T, Stokke BG, Røskaft E (2010). Does illegal hunting skew Serengeti wildlife sex ratio? Wildlife Biology 16(4):419-430.

Massawe A, Mrosso F, Makundi R, Mulungu L (2008). Breeding patterns of Arvicanthis neumanni in central Tanzania. African Journal of Ecology 46(3):320-324.

Massawe A, Rwamugira W, Leirs H, Makundi R, Mulungu LS (2006). Do farming practices influence population dynamics of rodents? A case study of the multimammate field rats, Mastomys natalensis, in Tanzania African Journal of Ecology 45(3):293-301.

Massawe AW, Leirs H, Rwamugira WP, Makundi RH (2003). Effect of land preparation methods on spatial distribution of rodents in crop fields. In: Rats, Mice and People: Rodent Biology and Management (Eds Singleton GR, Hinds LA, Krebs CJ, Spratt DM). Australian Centre for International Agricultural Research, Canberra.

Massawe AW, Makundi RH, Mulungu LS, Katakweba A, Shayo TN (2012). Breeding dynamics of rodent species inhabiting farm-fallow mosaic fields in Central Tanzania. African Zoology 47(1):128-137.

Massawe AW, Rwamugira W, Leirs H, Makundi RH, Mulungu L (2005). Influence of land preparation methods and vegetation cover on population abundance of Mastomys natalensis in Morogoro, Tanzania.

Monadjem A, Perrin M (2003). Population fluctuations and community structure of small mammals in a Swaziland grassland over a threeyear period. African Zoology 38(1):127-137.

Mulungu LS, Ngowo V, Mdangi M, Katakweba AS, Tesha P, Mrosso FP, Mchomvu M, Sheyo PM, Kilonzo BS (2013). Population dynamics and breeding patterns of multimammate mouse, Mastomys natalensis (Smith 1834), in irrigated rice fields in Eastern Tanzania. Pest Management Science 69(3):371-377.

Ndibalema VG (2009). A comparison of sex ratio, birth periods and calf survival among Serengeti wildebeest sub-populations, Tanzania. African Journal of Ecology 47(4):574-582.

Newbold T, Hudson LN, Hill SL, Contu S, Lysenko I, Senior RA, Börger L, Bennett DJ, Choimes A, Collen B (2015). Global effects of land use on local terrestrial biodiversity. Nature 520(7545):45.

Newsome A (1969a). A population study of house-mice permanently inhabiting a reed-bed in South Australia. The Journal of Animal Ecology 361-377.

Newsome A (1969b). A population study of house-mice temporarily inhabiting a South Australian wheatfield. The Journal of Animal Ecology 341-359.

Nicolas V, Colyn M (2003). Seasonal variations in population and community structure of small rodents in a tropical forest of Gabon. Canadian Journal of Zoology 81(6):1034-1046.

Nkwabi AK, John B, Kija H, Otsyina RM, Monjare JF, Kajuni AR (2018). Abundance and distribution of small mammals relative to human activities in the wildlife management areas of Ruvuma landscape, southern Tanzania. International Journal of Fauna and Biological Studies 5(2):156-162.

Norton-Griffiths M, Herlocker D, Pennycuick L (1975). The patterns of rainfall in the Serengeti ecosystem, Tanzania. African Journal of Ecology 13(3-4):347-374.

Odhiambo R, Makundi R, Leirs H, Verhagen R (2005). Community structure and seasonal abundance of rodents of maize farms in southwestern Tanzania. doi:http://hdl.handle.net/123456789/1041

Olenev G, Grigorkina E (2011). Dynamics of sex ratio in populations of cyclomorphic mammals (rodentia, cricetidae, muridae). Biology Bulletin 38(8):797-808.

Oli MK, Dobson FS (1999). Population cycles in small mammals: the role of age at sexual maturity. Oikos 557-565.

Peles JD, Barrett GW (1996). Effects of vegetative cover on the population dynamics of meadow voles. Journal of Mammalogy 77(3):857-869.

Phelps KL (2006). Ecological characteristics of small mammal communities inhabiting Tar Creek Superfund Site, Oklahoma. Oklahoma State University,

Rankin DJ, Dieckmann U, Kokko H (2011). Sexual conflict and the tragedy of the commons. The American Naturalist 177(6):780-791.

Reed D, Anderson T, Dempewolf J, Metzger K, Serneels S (2009). The spatial distribution of vegetation types in the Serengeti ecosystem: the influence of rainfall and topographic relief on vegetation patch characteristics. Journal of Biogeography 36(4):770-782.

Reichman O, Van De Graaff KM (1975). Association between ingestion of green vegetation and desert rodent reproduction. Journal of Mammalogy 56(2):503-506.

Rickart EA, Bienek KG, Rowe RJ (2013). Impact of livestock grazing on plant and small mammal communities in the Ruby Mountains, northeastern Nevada. Western North American Naturalist 73(4):505515

Rosenfeld CS, Roberts RM (2004). Maternal diet and other factors affecting offspring sex ratio: a review. Biology of Reproduction 71(4):1063-1070.

Sarli J, Lutermann H, Alagaili AN, Mohammed OB, Bennett NC (2016). Seasonal reproduction in the Arabian spiny mouse, Acomys dimidiatus (Rodentia: Muridae) from Saudi Arabia: the role of rainfall and temperature. Journal of Arid Environments 124:352-359.

Schärer L, Rowe L, Arnqvist G (2012). Anisogamy, chance and the evolution of sex roles. Trends in Ecology and Evolution 27(5):260264.

Schieltz JM, Rubenstein DI (2016). Evidence based review: positive versus negative effects of livestock grazing on wildlife. What do we really know? Environmental Research Letters 11(11):113003.

Schmidt NM, Olsen H, Bildsøe M, Sluydts V, Leirs H (2005). Effects of grazing intensity on small mammal population ecology in wet meadows. Basic and Applied Ecology 6(1):57-66.

Searle $J$ (1985). Methods for determining the sex of common shrews (Sorex araneus). Journal of Zoology 206(2):279-282.

Setsaas TH, Holmern T, Mwakalebe G, Stokke S, Røskaft E (2007). How does human exploitation affect impala populations in protected and partially protected areas?-A case study from the Serengeti Ecosystem, Tanzania. Biological Conservation 136(4):563-570.

Sinclair A (2008). Integrating conservation in human and natural systems. In 'Serengeti III: Human Impacts on Ecosystem Dynamics'.(Eds Sinclair ARE, Packer C, Mduma SAR, Fryxell JM) University of Chicago Press: Chicago. pp. 471-495.

Soholt LF (1977). Consumption of herbaceous vegetation and water during reproduction and development of Merriam's kangaroo rat, Dipodomys merriami. American Midland Naturalist 445-457.

Stanley WT, Goodman SM, Newmark WD (2011). Small mammal inventories in the East and West Usambara Mountains, Tanzania. Study areas, methodologies, and general results. Fieldiana Life and Earth Sciences, pp. 1-17.

Stephens PA, Sutherland WJ (1999). Consequences of the Allee effect for behaviour, ecology and conservation. Trends in Ecology and Evolution 14(10): 401-405.

Tabeni S, Ojeda R (2005). Ecology of the Monte Desert small mammals in disturbed and undisturbed habitats. Journal of Arid Environments 63(1):244-255.

Taylor K, Green M (1976). The influence of rainfall on diet and reproduction in four African rodent species. Journal of Zoology 180(3):367-389.

Tittensor DP, Walpole M, Hill SL, Boyce DG, Britten GL, Burgess ND, Butchart SH, Leadley PW, Regan EC, Alkemade R (2014). A midterm analysis of progress toward international biodiversity targets. Science 346(6206):241-244

Trivers RL, Willard DE (1973). Natural selection of parental ability to 
vary the sex ratio of offspring. Science 179(4068):90-92.

Twining JP, Bernard H, Ewers RM (2017). Increasing land-use intensity reverses the relative occupancy of two quadrupedal scavengers. PLoS ONE 12(5):e0177143.

Visser ME, Both C (2005). Shifts in phenology due to global climate change: the need for a yardstick. Proceedings of the Royal Society B: Biological Sciences 272(1581):2561-2569.

Williams CT, Klaassen M, Barnes BM, Buck CL, Arnold W, Giroud S, Vetter SG, Ruf T (2017). Seasonal reproductive tactics: annual timing and the capital-to-income breeder continuum. Philosophical Transactions of the Royal Society. Biological Sciences 372(1734):20160250.

Winer B (1971). Statistical Principles in Experimental Design: 2d Ed: McGraw-Hill.

Wirminghaus J, Perrin M (1993). Seasonal changes in density, demography and body composition of small mammals in a southern temperate forest. Journal of Zoology 229(2):303-318.

Wube T (2005). Reproductive rhythm of the grass rat Arvicanthis abyssinicus, at the Entoto Mountain, Ethiopia. Belgian Journal of Zoology 135:53-56.

Zhang J, Zhang Z (2003). Influence of operational sex ratio and density on the copulatory behaviour and mating system of Brandt's voleMicrotus brandti. Acta Theriologica 48(3):335-346. 


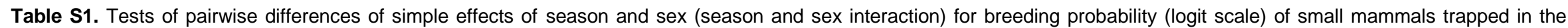
Serengeti Ecosystem during 2017 and 2018 based on the logistic regression model.

\begin{tabular}{|c|c|c|c|c|c|c|c|c|c|c|c|}
\hline $\begin{array}{c}\text { Statement } \\
\text { number }\end{array}$ & Effect & Slice & Season & Season & Difference estimate & Standard error & DF & tValue & $\operatorname{Pr}>|t|$ & 95\% Lower CL & 95\% Upper CL \\
\hline 1 & Season $\times$ Sex & Sex $F$ & Dry & Wet & -2.461 & 0.5753 & 11 & -4.28 & 0.001 & -3.728 & -1.19 \\
\hline 1 & Season $\times$ Sex & Sex M & Dry & Wet & -0.708 & 0.3075 & 11 & -2.31 & 0.042 & -1.386 & -0.03 \\
\hline 2 & Season $\times$ Sex & \multicolumn{2}{|c|}{ Season Dry } & & 1.001 & 0.3657 & 11 & 2.74 & 0.019 & 0.197 & 1.807 \\
\hline 2 & Season $\times$ Sex & \multicolumn{2}{|c|}{ Season Wet } & & 2.754 & 0.5402 & 11 & 5.1 & $3 \times 10^{-4}$ & 1.566 & 3.944 \\
\hline
\end{tabular}

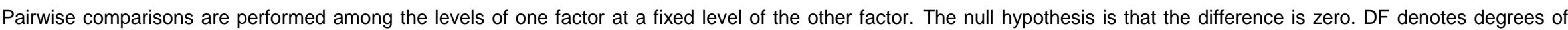
freedom.

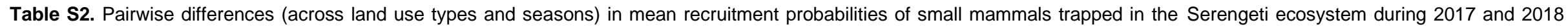
based on the logistic regression model.

\begin{tabular}{|c|c|c|c|c|c|c|c|c|c|c|c|}
\hline Effect & Landuse & Season & Landuse & Season & Difference Estimate & Standard error & DF & t Value & $\operatorname{Pr}>|t|$ & $\begin{array}{c}95 \% \\
\text { Lower CL }\end{array}$ & $\begin{array}{c}95 \% \\
\text { Upper CL }\end{array}$ \\
\hline Landuse & Agricultural & & National park & & 0.755 & 0.5952 & 8 & 1.27 & 0.24 & -0.62 & 2.1276 \\
\hline Landuse & Agricultural & & Pastoral & & -1.406 & 0.462 & 8 & -3.04 & 0.016 & -2.47 & -0.3406 \\
\hline Landuse & National park & & Pastoral & & -2.1611 & 0.459 & 8 & -4.71 & 0.002 & -3.22 & -1.1025 \\
\hline Season & & Dry & & Wet & 0.9984 & 0.4059 & 8 & 2.46 & 0.039 & 0.062 & 1.9345 \\
\hline
\end{tabular}

Table S3. Adjusted mean sex ratio and the associated 95\% confidence limits (CL) for small mammals trapped in the Serengeti Ecosystem during 2017 and 2018 based on the logistic regression model.

\begin{tabular}{llccccc}
\hline Effect & Landuse & Sex & Mean sex ratio & Standard error & 95\% Lower CL & 95\% Upper CL \\
\hline Sex & & F & 0.2751 & 0.02402 & 0.1844 & 0.3892 \\
Sex & & M & 0.7249 & 0.02402 & 0.6108 & 0.8156 \\
Landuse $\times$ Sex & Agriculture & F & 0.1563 & 0.03926 & 0.04892 & 0.4001 \\
Landuse $\times$ Sex & Agriculture & M & 0.8437 & 0.03926 & 0.5999 & 0.9511 \\
Landuse $\times$ Sex & Park & F & 0.2878 & 0.03055 & 0.1755 & 0.4342 \\
Landuse $\times$ Sex & Park & M & 0.7122 & 0.03055 & 0.5658 & 0.8245 \\
Landuse $\times S e x$ & Pastoral & F & 0.4221 & 0.03406 & 0.286 & 0.5712 \\
Landuse $\times$ Sex & Pastoral & M & 0.5779 & 0.03406 & 0.4288 & 0.714 \\
\hline
\end{tabular}

$\mathrm{F}$ and $\mathrm{M}$ denote females and males, respectively. 
Table S4. Pairwise differences (across land use types and sex on the logit link scale) of the mean sex ratio and the associated $95 \%$ confidence limits (CL) of small mammals trapped in the Serengeti ecosystem during 2017 and 2018 based on the logistic regression model. DF denotes degrees of freedom.

\begin{tabular}{|c|c|c|c|c|c|c|c|c|c|c|c|}
\hline Effect & Landuse & Sex & Landuse & Sex & $\begin{array}{c}\text { Difference } \\
\text { estimate }\end{array}$ & $\begin{array}{c}\text { Standard } \\
\text { error }\end{array}$ & DF & t Value & $\operatorname{Pr}>|t|$ & $\begin{array}{c}95 \% \\
\text { Lower CL } \\
\end{array}$ & $\begin{array}{c}95 \% \\
\text { Upper CL }\end{array}$ \\
\hline Sex & & $\mathrm{F}$ & & $M$ & -1.9374 & 0.1677 & 2 & -11.55 & 0.0074 & -2.659 & -1.2158 \\
\hline Landuse $\times$ Sex & Agriculture & $\mathrm{F}$ & Agriculture & $M$ & -3.3725 & 0.4135 & 2 & -8.16 & 0.0147 & -5.1517 & -1.5932 \\
\hline Landuse $\times$ Sex & Agriculture & $\mathrm{F}$ & Park & $\mathrm{F}$ & -0.7803 & 0.3335 & 2 & -2.34 & 0.1442 & -2.2153 & 0.6547 \\
\hline Landuse $\times$ Sex & Agriculture & $\mathrm{F}$ & Park & $M$ & -2.5921 & 0.3324 & 2 & -7.8 & 0.0161 & -4.0225 & -1.1618 \\
\hline Landuse $\times$ Sex & Agriculture & $\mathrm{F}$ & Pastoral & $\mathrm{F}$ & -1.3722 & 0.3272 & 2 & -4.19 & 0.0524 & -2.7802 & 0.03575 \\
\hline Landuse $\times$ Sex & Agriculture & $\mathrm{F}$ & Pastoral & $M$ & -2.0002 & 0.3305 & 2 & -6.05 & 0.0262 & -3.4222 & -0.5782 \\
\hline Landuse $\times$ Sex & Agriculture & $M$ & Park & $\mathrm{F}$ & 2.5921 & 0.3324 & 2 & 7.8 & 0.0161 & 1.1618 & 4.0225 \\
\hline Landuse $\times$ Sex & Agriculture & $M$ & Park & $M$ & 0.7803 & 0.3335 & 2 & 2.34 & 0.1442 & -0.6547 & 2.2153 \\
\hline Landuse $\times$ Sex & Agriculture & $M$ & Pastoral & $\mathrm{F}$ & 2.0002 & 0.3305 & 2 & 6.05 & 0.0262 & 0.5782 & 3.4222 \\
\hline Landuse $\times$ Sex & Agriculture & $M$ & Pastoral & $M$ & 1.3722 & 0.3272 & 2 & 4.19 & 0.0524 & -0.0358 & 2.7802 \\
\hline Landuse $\times$ Sex & Park & $\mathrm{F}$ & Park & $M$ & -1.8118 & 0.2102 & 2 & -8.62 & 0.0132 & -2.7162 & -0.9073 \\
\hline Landuse $\times$ Sex & Park & $\mathrm{F}$ & Pastoral & $\mathrm{F}$ & -0.5919 & 0.2055 & 2 & -2.88 & 0.1024 & -1.4761 & 0.2923 \\
\hline Landuse $\times$ Sex & Park & $\mathrm{F}$ & Pastoral & $M$ & -1.2199 & 0.2029 & 2 & -6.01 & 0.0266 & -2.093 & -0.3467 \\
\hline Landuse $\times$ Sex & Park & $M$ & Pastoral & $\mathrm{F}$ & 1.2199 & 0.2029 & 2 & 6.01 & 0.0266 & 0.3467 & 2.093 \\
\hline Landuse $\times$ Sex & Park & $M$ & Pastoral & $M$ & 0.5919 & 0.2055 & 2 & 2.88 & 0.1024 & -0.2923 & 1.4761 \\
\hline Landuse $\times$ Sex & Pastoral & $\mathrm{F}$ & Pastoral & $\mathrm{M}$ & -0.628 & 0.1929 & 2 & -3.25 & 0.0828 & -1.4581 & 0.2021 \\
\hline
\end{tabular}

S1 Data. The total number of adult (Age=A) male (Sex=M) and female (Sex=F) breeding and non-breeding small mammals captured in three land uses in the Tanzania Serengeti Ecosystem in the wet and dry seasons of 2017 and 2018.

\begin{tabular}{|c|c|c|c|c|c|c|c|c|c|c|c|c|}
\hline Year & Land use & Season & Sex & Age & $\begin{array}{c}\text { Total } \\
\text { number } \\
\text { Breeding }\end{array}$ & $\begin{array}{c}\text { Total } \\
\text { number not } \\
\text { breeding }\end{array}$ & $\begin{array}{c}\text { Total } \\
\text { number } \\
\text { captured }\end{array}$ & $\begin{array}{c}\text { Total } \\
\text { trap } \\
\text { nights }\end{array}$ & logTrapnights & Prob & $\begin{array}{c}\text { Lower } 95 \% \\
\text { prediction } \\
\text { Limit for } \\
\text { Prob }\end{array}$ & $\begin{array}{c}\text { Upper } 95 \% \\
\text { prediction } \\
\text { Limit for } \\
\text { Prob }\end{array}$ \\
\hline 2017 & National Park & Wet & $\mathrm{F}$ & $A$ & 7 & 1 & 8 & 11280 & 9.33079 & 0.8 & 0.59428 & 0.91613 \\
\hline 2017 & National Park & Wet & $M$ & $A$ & 3 & 16 & 19 & 11280 & 9.33079 & 0.16304 & 0.09475 & 0.26609 \\
\hline 2017 & National Park & Dry & $\mathrm{F}$ & $A$ & 1 & 3 & 4 & 11280 & 9.33079 & 0.18182 & 0.07604 & 0.37503 \\
\hline 2017 & National Park & Dry & M & A & 1 & 22 & 23 & 11280 & 9.33079 & 0.06557 & 0.02198 & 0.17971 \\
\hline 2017 & Pastoral Land & Wet & $\mathrm{F}$ & A & 22 & 2 & 24 & 5640 & 8.63764 & 0.94444 & 0.77413 & 0.98828 \\
\hline 2017 & Pastoral Land & Wet & $M$ & A & 7 & 15 & 22 & 5640 & 8.63764 & 0.36111 & 0.20846 & 0.54814 \\
\hline 2017 & Pastoral Land & Dry & $\mathrm{F}$ & $A$ & 4 & 8 & 12 & 5640 & 8.63764 & 0.4697 & 0.3398 & 0.60384 \\
\hline
\end{tabular}




\begin{tabular}{llllllccccccc}
2017 & Pastoral Land & Dry & M & A & 2 & 32 & 34 & 5640 & 8.63764 & 0.17647 & 0.10793 \\
2017 & Agricultural Land & Wet & F & A & 0 & 0 & 0 & 11280 & 9.33079 & 0.66667 & 0.11894 & 0.96735 \\
2017 & Agricultural Land & Wet & M & A & 1 & 7 & 8 & 11280 & 9.33079 & 0.24138 & 0.10907 & 0.45264 \\
2017 & Agricultural Land & Dry & F & A & 0 & 3 & 3 & 11280 & 9.33079 & 0.3 & 0.08579 & 0.66184 \\
2017 & Agricultural Land & Dry & M & A & 7 & 18 & 25 & 11280 & 9.33079 & 0.21739 & 0.11228 & 0.37891 \\
2018 & National Park & Wet & F & A & 17 & 5 & 22 & 11280 & 9.33079 & 0.8 & 0.59428 & 0.91613 \\
2018 & National Park & Wet & M & A & 12 & 61 & 73 & 11280 & 9.33079 & 0.16304 & 0.09475 & 0.26609 \\
2018 & National Park & Dry & F & A & 5 & 24 & 29 & 11280 & 9.33079 & 0.18182 & 0.07604 & 0.37503 \\
2018 & National Park & Dry & M & A & 3 & 35 & 38 & 11280 & 9.33079 & 0.06557 & 0.02198 & 0.17971 \\
2018 & Pastoral Land & Wet & F & A & 12 & 0 & 12 & 5640 & 8.63764 & 0.94444 & 0.77413 & 0.98828 \\
2018 & Pastoral Land & Wet & M & A & 6 & 8 & 14 & 5640 & 8.63764 & 0.36111 & 0.20846 & 0.54814 \\
2018 & Pastoral Land & Dry & F & A & 27 & 27 & 54 & 5640 & 8.63764 & 0.4697 & 0.3398 & 0.60384 \\
2018 & Pastoral Land & Dry & M & A & 16 & 52 & 68 & 5640 & 8.63764 & 0.17647 & 0.10793 & 0.27512 \\
2018 & Agricultural Land & Wet & F & A & 2 & 1 & 3 & 11280 & 9.33079 & 0.66667 & 0.11894 & 0.96735 \\
2018 & Agricultural Land & Wet & M & A & 6 & 15 & 21 & 11280 & 9.33079 & 0.24138 & 0.10907 & 0.45264 \\
2018 & Agricultural Land & Dry & F & A & 3 & 4 & 7 & 11280 & 9.33079 & 0.3 & 0.08579 & 0.66184 \\
2018 & Agricultural Land & Dry & M & A & 3 & 18 & 21 & 11280 & 9.33079 & 0.21739 & 0.11228 & 0.37891 \\
\hline
\end{tabular}

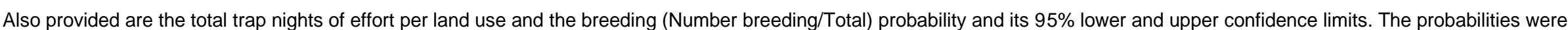
predicted using a logistic regression model with a binomial error distribution, a logit link function and the logarithm of trap night as the offset.

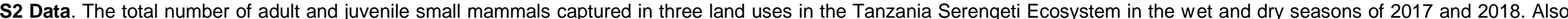

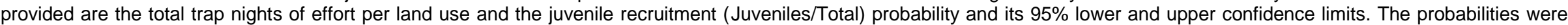
predicted using a logistic regression model with a binomial error distribution, a logit link function and the logarithm of trap night as the offset.

\begin{tabular}{|c|c|c|c|c|c|c|c|c|c|c|}
\hline Year & Land use & Season & Adults & Juveniles & Total & Trapnight & logTrapnight & Prob & $\begin{array}{c}\text { Lower } 95 \% \text { Prediction } \\
\text { Limit for Prob }\end{array}$ & $\begin{array}{c}\text { Upper } 95 \% \text { Prediction } \\
\text { Limit for Prob }\end{array}$ \\
\hline 2017 & National Park & Wet & 30 & 0 & 30 & 11280 & 9.33079 & 0.01463 & 0.0047 & 0.04459 \\
\hline 2017 & National Park & Dry & 32 & 3 & 35 & 11280 & 9.33079 & 0.03875 & 0.01455 & 0.09913 \\
\hline 2017 & Pastoral Land & Wet & 46 & 8 & 54 & 5640 & 8.63764 & 0.06056 & 0.02566 & 0.13626 \\
\hline 2017 & Pastoral Land & Dry & 46 & 24 & 70 & 5640 & 8.63764 & 0.14889 & 0.10029 & 0.21541 \\
\hline 2017 & Agricultural Land & Wet & 8 & 0 & 8 & 11280 & 9.33079 & 0.03063 & 0.0091 & 0.09802 \\
\hline 2017 & Agricultural Land & Dry & 28 & 5 & 33 & 11280 & 9.33079 & 0.07899 & 0.03081 & 0.18792 \\
\hline
\end{tabular}




\begin{tabular}{llccccccccc}
\hline 2018 & National Park & Wet & 102 & 0 & 102 & 11280 & 9.33079 & 0.01463 & 0.0047 & 0.04459 \\
2018 & National Park & Dry & 67 & 3 & 70 & 11280 & 9.33079 & 0.03875 & 0.01455 & 0.09913 \\
2018 & Pastoral Land & Wet & 28 & 0 & 28 & 5640 & 8.63764 & 0.06056 & 0.02566 & 0.13626 \\
2018 & Pastoral Land & Dry & 123 & 2 & 125 & 5640 & 8.63764 & 0.14889 & 0.10029 & 0.21541 \\
2018 & Agricultural Land & Wet & 28 & 0 & 28 & 11280 & 9.33079 & 0.03063 & 0.0091 & 0.09802 \\
2018 & Agricultural Land & Dry & 28 & 1 & 29 & 11280 & 9.33079 & 0.07899 & 0.03081 & 0.18792 \\
\hline
\end{tabular}

